\title{
Politiets brug af peberspray - en skandinavisk sammenligning med fokus på Danmark
}

\author{
Af Lars Holmberg ${ }^{1}$
}

\begin{abstract}
This paper discusses the use of pepper spray (OC-spray) in the Scandinavian police forces with a special emphasis on Denmark. Since the spray's introduction to Denmark in 2008, it has been used about 1450 times annually. The use of pepper spray does not seem to have caused any substantial reduction in the use of other kinds of force by police, as was predicted in the trial preceding its introduction to the force. A limited comparison with Norway suggests that the Danish police use pepper spray far more frequently than their Norwegian counterparts. This may be due to the fact that the rules surrounding pepper spray use are more lenient in Denmark than Norway.
\end{abstract}

\section{Indledning}

Fra og med 2008 har alle nordiske landes politistyrker været udstyret med peberspray. De slutter sig hermed til en stor kreds af lande i den vestlige verden, anført af USA, som benytter dette våben i politiarbejdet. Hovedargumentet for indførelsen i Norden har været, at peberspray kan uskadeliggøre en person på afstand, og at politiet dermed undgår at gribe til mere håndfaste metoder med den risiko for skader på såvel borgere som politipersonel, dette kan medføre. Siden indførelsen har brugen af sprayen, med Sverige som eneste undtagelse, ikke været genstand for systematisk diskussion, ${ }^{2}$ og der findes, så vidt vides, ikke nogen nordisk forskning på området.

I denne artikel vil jeg, på baggrund af den internationale forskning om pebersprayens anvendelse og virkning, redegøre for, hvad der faktisk vides om politiets brug peberspray i Norge, Sverige og Danmark. Peberspray anvendes også af det finske og det islandske politi, men data fra disse lande er så begrænsede, at de ikke vil blive inddraget her. Artiklen har særligt fokus på Danmark, hvorfra der foreligger detaljerede data, ikke bare om brugen af peberspray, men også om politi-

* Title in English: Police use of pepper spray in Denmark 
ets brug af magtmidler i det hele taget, hvilket ikke er tilfældet i de øvrige nordiske lande.

Efter indførelsen af peberspray er det samlede antal indberetninger om politiets brug af magtmidler i Danmark mere end tredoblet, og brug af sprayen synes ikke at have reduceret brugen af andre magtmidler (stav og skydevåben) væsentligt. En sammenligning mellem Danmark og Norge tyder på, at dansk politi bruger peberspray langt oftere end deres norske kolleger. På baggrund af de tilgængelige oplysninger må man spørge, om indførelsen af peberspray i Danmark har haft den virkning, der var ønsket, og om den alene bruges på den måde, det oprindeligt var tanken.

\section{Peberspray - virkning og anvendelse}

Peberspray, også kaldet OC (Oleoresin Capsicum), består af et udtræk af cayennepeber iblandet et opløsningsmiddel og påfyldt en spraydåse, som indeholder et drivmiddel. ${ }^{3}$ Det anvendes ved at spraye mod en persons ansigt og medfører øjeblikkeligt stærke smerter i øjne og på huden, tåreflåd og flåd fra næsen, vanskeligheder med vejrtrækningen, samt ufrivillig blinken med eller lukning af øjnene. Når en person udsættes for peberspray, bliver vedkommende i de fleste tilfælde ude af stand til at orientere sig og tvinges til at opgive et eventuelt angreb/fysisk modstand. Personen kan efterfølgende hjælpes med at skylle øjne og hud med vand, hvilket generelt reducerer/fjerner virkningen temmelig hurtigt - i lande, hvor peberspray anvendes, er der normalt krav om, at politiet skal hjælpe den ramte med at afhjælpe generne, når formålet med brugen af sprayen er opnået.

Siden amerikansk politi begyndte at bruge peberspray sidst i 1980'erne, har der været en række anklager om dødsfald i forbindelse med brugen af sprayen, særligt blandt personer, som var i politiets varetægt. ${ }^{4}$ Undersøgelser af disse sager peger stort set entydigt på, at peberspray ikke har været den udløsende faktor for dødsfaldene (se f.eks. Busker og van Helden 1998, Smith og Greaves 2002, NIJ 2003, Vilke og Chan 2007). De fleste forskere mener endvidere, at brugen af peberspray i det hele taget ikke forårsager blivende skader. Der ses af og til øjenskader som følge af, at den udsatte person gnider sig i øjnene, men heller ikke disse er af blivende karakter (Vesaluoma et al. 2000).

En undtagelse er Smith og Stopford (1999), som opregner en række mulige risici ved brug af peberspray. De gør opmærksom på, at US Department of Labor i 1993 advarede mod, at politipersonale blev udsat for spray som led i deres træning, fordi det kunne medføre helseproblemer. En upubliceret undersøgelse foretaget af den ene af forfatterne viser, at cirka én procent af godt 6000 politifolk, som var blevet sprayet under uddannelse, fik symptomer, som ikke forsvandt 
umiddelbart. Smith og Stopford gør også opmærksom på, at FBIs positive vurdering af peberspray (Weaver og Jett 1989) er utroværdig, fordi en af forskerne bag FBIs vurdering viste sig at have modtaget penge fra en producent af peberspray. Smith og Stopford mener generelt, at peberspray bør være en del af politiets arsenal, men advarer om, at »[a]necdotal, research, and clinical data on the adverse effects of OC sprays are now sufficient to say that the hazards of these products ought to be more objectively and thoroughly evaluated and more clearly communicated « (Smith og Stopford 1999:273). Interessant nok citeres denne artikel slet ikke i de senest publicerede oversigter over virkningen af forskellige typer ikkedræbende magtmidler (Virk og Chan 2007, Smith et al. 2010), mens en tidligere oversigt alene citerer artiklen for, at peberspray kan reducere skader på anholdte (Smith og Greaves 2002: 599). Der synes således at være en vis tendens i forskningslitteraturen til at overvurdere de positive sider af OC-spray.

\subsection{Er peberspray effektiv?}

Der er gennemført en række undersøgelser af pebersprayens effektivitet i USA (se f.eks. Edwards, Granfield og Onnen 1995, Lumb og Friday 1997, Morabito og Doerner 1997, Kaminski, Edwards og Johnson 1999), og disse peger generelt på, at sprayen er temmelig virksom, når det gælder at uskadeliggøre de personer, der rammes. Undersøgelserne er af svingende kvalitet; antallet af cases varierer fra 61 til 690, og der er i bedste fald tale om før og efter-undersøgelser. Generelt ses det, at mellem 70 og 85 pct. af de ramte personer uskadeliggøres i en grad, der gør anholdelse mulig uden yderligere magtanvendelse fra politiets side. De fleste af de her nævnte studier finder dog, at OC-spray er mindre effektiv eller helt virkningsløs over for mentalt forstyrrede personer og personer, som er påvirket af narkotika. Kaminski, Edwards og Johnson (1999) viser, at politifolkenes vurdering af sprayen tenderer til at være mere positiv end der er basis for: Betjentene mente, at sprayen havde hjulpet dem under anholdelsen i 85 pct. af tilfældene, mens sprayen iflg. de enkelte indberetninger kun havde inkapaciteret den anholdte $i 1$ pct. af tilfældene.

Det har også været hævdet, at den blotte tilstedeværelse af spray i politiets arsenal har en præventiv effekt - kaldet Velcro-effekten, fordi spraydåsen typisk sidder i et etui med Velcrolukke, som giver en let genkendelig lyd, når det åbnes. Denne hypotese er dog kun støttet af en enkelt undersøgelse (Kaminski, Smith og Johnson 1998), hvis resultat er blevet anfægtet (Buttle 2006).

En række studier hævder, at indførelsen af OC reducerer fysiske skader på såvel politipersonale som på anholdte. Der synes dog at være en tendens til at overdrive virkningen af sprayen. For eksempel skriver det amerikanske National Insti- 
tute of Justice i en oversigt over forskning på området, at en undersøgelse gennemført i tre politidistrikter i North Carolina »found that the number of injuries to police officers and suspects declined after pepper spray was introduced « (NIJ 2003: ii). Læser man den oprindelige undersøgelse (Bowling og Gaines 2000) viser det sig imidlertid, at sprayen var associeret med en reduktion af skader på politifolk i ét distrikt, og med reduktion af skader på anholdte i et andet distrikt. Der var altså kun påvist statistisk signifikante virkninger af $\mathrm{OC}$ i to af seks mulige tilfælde. Selv om dette fremgår indirekte længere fremme i NIJs oversigt, giver denne umiddelbart læseren indtryk af, at begge former for skader blev reduceret $\mathrm{i}$ alle tre distrikter.

Disse resultater sættes i relief af den senest gennemførte, større studie i USA. Undersøgelsen (Smith et al. 2010), som er baseret på over 24.000 politiindberetninger om brug af magtmidler, bekræfter, at brugen af peberspray reducerer risikoen for, at anholdte får varige fysiske skader i forbindelse med anholdelsen. Interessant nok finder man samtidig, at risikoen for fysiske skader på politipersonale øges med 22-39 procent, ${ }^{5}$ et resultat, forfatterne ikke har nogen forklaring på.

Stort set al eksisterende forskning på dette område stammer fra USA, og en britisk forsker (Rappert 2002) har kritiseret den tidlige amerikanske forskning for at være af dårlig videnskabelig kvalitet. Han mener, at effekten af peberspray derfor er væsentlig overvurderet. Der findes en enkelt studie gennemført i Holland: Ifølge Adang et al. (2006) viste en evaluering af peberspray i en række politidistrikter, at hollandsk politi overordnet var meget tilfredse med pebersprayen, om end der var eksempler på, at brug af peberspray øger aggressiviteten hos ellers ikke-aggressive personer. En senere undersøgelse baseret på de samme data viser, at indførelsen af peberspray i det hollandske politi $i k k e$ reducerede politiets brug af andre former for magtmidler, sådan som det ellers ses at være sket i USA (Kaminski og Adang 2010). Forfatterne mener, at dette må skyldes, at pebersprayen har afløst anden magtanvendelse, f.eks. håndgemæng, som ikke tidligere blev rapporteret. Der sås også eksempler på, at peberspray blev anvendt i stedet for verbal kommunikation. Tilsvarende fandt Lumb og Friday (1997) i en tidlig amerikansk studie, at politiets magtanvendelse steg, da betjentene fik adgang til peberspray. De fandt tillige, at selv om de politifolk, som faktisk anvendte peberspray, ikke rapporterede om fysiske skader i disse episoder, steg det samlede antal af skader på politifolk i forbindelse med indførelsen af sprayen. Forfatternes hypotese var, at besiddelsen af peberspray gjorde politifolkene overmodige, og at de derfor indlod sig i konfliktsituationer, de ellers ville have været mere forsigtige med. $^{6}$ 


\subsection{Hvornår må sprayen bruges?}

De tidlige, positive evalueringer af pebersprayens virkninger har betydet, at stort set alle amerikanske politiorganisationer i dag er udstyret med peberspray (NIJ 2003). Der er imidlertid forskel på, i hvilke situationer amerikansk politi kan bruge sprayen, som er placeret på forskellige trin af det såkaldte magtbarometer. Nogle steder indplaceres OC på linje med såkaldt »bløde« teknikker (greb, tryk), andre steder opfattes den som et »impact weapon « på linje med eller voldsommere end politistaven, og enkelte steder ses brug af spray som vold på linje med brug af skydevåben (Terrill, Paoline og Ingram 2012: 33-34). Indplaceringen på magtbarometeret har selvsagt betydning for, i hvilke situationer sprayen kan anvendes, og også her er der forskel: I nogle dele af landet kan sprayen anvendes mod personer som alene yder verbal eller passiv modstand (dvs. undlader at følge politiets ordrer), mens der i hovedparten af USA kræves i hvert fald defensiv modstand, hvor personen for eksempel søger at trække sig fri af politiets greb eller at holde fast $\mathrm{i}$ andre personer eller genstande. Et nyligt eksempel, hvor siddende demonstranter bliver sprayet, viser, at der kan være ganske vide grænser for, hvornår amerikanske politifolk føler det berettiget at bruge sprayen. ${ }^{7}$

Spørgsmålet om, hvornår det er rimeligt at anvende peberspray, har fået forbløffende lidt opmærksomhed inden for politiforskningen, som stort set alene har fokuseret på spørgsmålet om effektivitet, herunder hvordan denne bedst kan vurderes. Der findes en enkelt undtagelse: Smith og Alpert (2000) argumenterer for, at da brug af peberspray reducerer skader på såvel politi som mistænkte, men ikke selv fører til varige mén, bør den anvendes før anden form for fysisk magt overhovedet. Forfatterne mener, at pebersprayens potentiale på denne måde udnyttes bedst muligt, og at det er helt i sin orden at spraye mod personer, som alene yder verbal modstand.

Adang og Mensink (2007) erklærer sig helt uenige: Den hollandske afprøvning af peberspray viste for det første, at peberspray kan medføre problematiske situationer, for eksempel ved, at en eller flere af politifolkene bliver ramt af spray og derved sat midlertidigt ud af spillet, eller at de ramte personer bliver mere, og ikke mindre, aggressive. Der er også eksempler på, at de ramte går i panik og kommer til at skade sig selv, fordi de ikke kan se. For det andet peger forfatterne på, at en lav tærskel for brug af peberspray let kan føre til misbrug. De citerer således en af de deltagende politifolk for følgende udtalelse om, hvordan denne brugte sprayen:

»I use it very easily ... »You don't want to come? No?... Pssss « It's as simple as that. Why risk a fight, when you can do ... pssss ... and it’s all over?« (Adang og Mensink 2007: 215) 
Der var i prøveperioden stor forskel på, hvordan og hvor meget sprayen blev anvendt $\mathrm{i}$ forskellige hollandske politidistrikter (som dengang var uafhængige af hinanden og derfor ikke nødvendigvis havde samme retningslinjer). Kun i ét af de deltagende politidistrikter var det tilladt at bruge spray mod personer, som alene ydede verbal eller passiv modstand. I dette distrikt blev sprayen brugt tre til seks gange så hyppigt som i de øvrige distrikter. Der var flere eksempler på såkaldt »kreativ« brug af sprayen, for eksempel ved at politifolkene sprayede sig selv i hånden og derefter smurte sprayen ud $\mathrm{i}$ ansigtet på personen.

Adang og Mensink (2007) gør opmærksom på, at selve smerten ved brug af sprayen synes at være undervurderet. De deltagende politifolk berettede, at ramte personer græd som børn, og at sprayen gav meget stærke smerter, som langt fra hos alle forsvandt efter kort tid. I forbindelse med forsøget blev en del politifolk selv udsat for spray, og en del af dem rapporterede fortsatte gener i dagene efter, på trods af at de var blevet afvasket umiddelbart. Forfatterne mener, at mange hollandske politifolk er for dårligt trænede i andre former for magtbrug, og at peberspray på denne baggrund let kan blive den lette udvej på trods af de stærke smerter og den panik, sprayen kan udløse.

Ud over, at denne debat klart afspejler de store forskelle, der er mellem det hollandske og det amerikanske syn på rimelig magtanvendelse fra politiets side, tydeliggør den også, at det alene er spørgsmålet om varigheden - og ikke intensiteten - af den påførte smerte/skade, der spiller en rolle i den amerikanske vurdering af peberspray. Som en britisk forsker formulerer det: »when and how much pain is acceptable to inflict on members of the public is an important question no matter what the extent of long terms injuries sustained « (Rappert 2007: 482). Såvel den hollandske som nogle af de amerikanske undersøgelser omtaler den præventive effekt, hvilket tyder på, at der kan være tale om en meget voldsom oplevelse: Personer, der én gang har været udsat for peberspray, vil meget nødig prøve det igen; nogle vil hellere udsættes for slag med stav. Denne intense smerte og ubehag synes nærmest overset i den amerikanske litteratur, hvor også spørgsmålet om eventuelle psykiske skadevirkninger er helt fraværende.

Samlet set kan det konkluderes, at en stor del af den eksisterende forskning vedr. OC-spray er svag rent metodisk. Der synes dog næppe at være tvivl om, at brugen af sprayen reducerer antallet af alvorlige skader på anholdte i USA. Det er også klart, at politifolk såvel i USA som i Holland er tilfredse med sprayen; de mener, at den letter deres arbejde, og at den reducerer deres risiko for selv at komme til skade. Hvorvidt dette faktisk er tilfældet, er, set i lyset af den seneste undersøgelse (Smith et al 2010), mere usikkert, og der synes at være en tendens 
til overvurdering af sprayens effektivitet. Endelig er det et åbent spørgsmål, om besiddelsen af peberspray erstatter brugen af andre magtmidler.

\section{Peberspray i de skandinaviske lande}

Den tilgængelige viden om peberspray i Norden/Skandinavien er meget begrænset. Der er ganske vist gennemført en række afprøvninger/evalueringer af sprayen, men disse er ikke af en kvalitet, som giver noget særlig godt grundlag for at vurdere, om sprayen nedsætter risikoen for politifolk og anholdte, eller i hvilket omfang, brug af spray kan erstatte/reducere brugen af andre magtmidler. Kun i Danmark findes der pålidelige tal for brugen af spray på nationalt plan, hvilket gør sammenligninger på tværs af landene vanskelige. I det følgende beskriver jeg - efter en kort redegørelse for det (desværre begrænsede) datagrundlag, denne artikel bygger på - hvad der vides om brugen af peberspray i Norge, Sverige og Danmark.

\subsection{Datagrundlag}

Som nævnt indledningsvis, bruges peberspray i alle nordiske lande. Forinden indførelsen blev der i Finland, Norge, Sverige og Danmark ${ }^{8}$ gennemført en test af peberspray $i$ en eller flere politikredse. Alle fire undersøgelser er faldet positivt ud, hvorefter brugen af sprayen er udrullet til hele politiorganisationen.

Den finske undersøgelse - som ikke er offentligt tilgængelig - blev gennemført lige før år 2000, og en del af resultaterne ligger til grund for indførelsen af peberspray i Norge. Der findes tal for brugen af peberspray i det finske politi, men disse omfatter kun en del af de hændelser, hvor sprayen er anvendt. Det er således ikke muligt at sige noget mere præcist om omfanget af brug i Finland, og Finland vil derfor ikke blive inddraget i sammenligninger med de øvrige lande. Det samme gælder Island.

For Norges vedkommende har jeg har fået adgang til evalueringsrapporten om afprøvningen, som foregik i 2002-2003 (Politiets data- og materielltjeneste og Politihøgskolen 2007). Der findes ikke i Norge tal for brugen af peberspray på landsplan, da informationerne ifølge Politidirektoratet opbevares i de enkelte distrikter. Jeg har derfor skrevet til de 27 norske politidistrikter og anmodet om data. De indkomne svar giver imidlertid ikke mulighed for en mere præcis samlet vurdering af, hvor ofte norsk politi bruger OC-spray. For det første har ikke alle distrikter besvaret forespørgslen; for det andet har nogle af kredsene meddelt, at der ikke føres statistik over brugen af spray - i stedet findes oplysninger herom i de enkelte sagsakter og kan ikke umiddelbart trækkes ud. I alt har jeg modtaget tal fra fire politidistrikter: Oslo, Søndre Buskerud, Vestfold og Vestoppland. 
I Sverige gennemførtes en afprøvning i 6 politidistrikter fra september 2002 til august 2003. Jeg har her fået adgang til den oprindelige evalueringsrapport (Rikspolisstyrelsen 2004). Der findes tillige en grundig gennemgang af forsøgets resultater i en senere undersøgelse af svensk politis brug af peberspray (Rikspolisen 2007). I denne rapport findes tillige tal for brugen af sprayen i Sverige i 2006, men på daværende tidspunkt var peberspray ikke fuldt udrullet i det svenske politi. Herudover bygger gennemgangen af de svenske tal på en rapport fra Justitieombudsmannen (2009). Jeg har tillige haft adgang til 4 eksamensopgaver fra Polishögskolans grunduddannelse, som hver især omhandler brugen af spray i ét svensk politidistrikt. Da der er meget store forskelle fra distrikt til distrikt (mellem 20 og 111 årlige anvendelser pr. distrikt), er det ikke muligt at vurdere omfanget af spraybrug i Sverige som helhed. Da det svenske politi ikke hidtil har ført samlet statistik over brugen af peberspray, kan der ikke foretages nationale sammenligninger.

I Danmark har jeg fået adgang til såvel evalueringsrapporten om pebersprayforsøget i 2006 (Rigspolitiet 2007) som de data, der ligger til grund for rapporten. Jeg har endvidere fra Rigspolitiet fået data for brugen af peberspray i perioden 2008-2011, herunder karakteristika ved de enkelte situationer, hvor sprayen er anvendt, samt tal for brug af stav og skydevåben.

Samlet set er den redegørelse for landenes brug af peberspray, som findes i det følgende, derfor ikke fyldestgørende, men den afspejler de oplysninger, det har været muligt at fremskaffe. ${ }^{9}$

\subsection{Peberspray $i$ Norge}

Den norske rapport om afprøvningen af peberspray (Politiets data- og materielltjeneste og Politihøgskolen 2007) bygger på 247 indberetninger fra 26 ud af Norges 27 politidistrikter i perioden 2003-2004. Rapporten konkluderer, at peberspray skabte øget tryghed hos polititjenestemændene, og i nogle af distrikterne mente man også, at sprayen havde reduceret brugen af andre magtmidler og dermed skader på anholdte. For at få lov at anvende sprayen skulle politifolkene gennemgå et kursus, hvor de blandt andet selv skulle udsættes for sprayen. Otte betjente fik efterfølgende fået længerevarende eller varige skader, blandt andet $\mathrm{i}$ øjnene. Dette fik i 2007 Arbeidstilsynet til at forbyde, at politifolk udsattes for spray som led i oplæringen, da det ikke kunne »utelukkes at det kan medføre helsefare « (Arbeidstilsynet 2007: 12). Politidirektoratet fastholdt imidlertid, at det var en forudsætning for godkendelse, at betjentene selv havde prøvet at blive ramt af sprayen (blandt andet for at forberede dem bedst muligt, hvis de skulle blive ramt ved et uheld). Herved gik sagen i hårdknude, og et større antal betjente kunne ikke 
godkendes til at bruge sprayen. ${ }^{10}$ Siden er uddannelsen ændret, således at betjentene ikke længere selv skal sprayes i ansigtet, men i stedet skal spraye en dukke, som de efterfølgende skal tage i varetægt og hjælpe med at afvaske sprayen. Der kan i denne sammenhæng forekomme sekundær udsættelse for sprayen, men denne er typisk af væsentlig mindre omfang end ved den tidligere metode.

I den norske hovedinstruks vedr. politiets brug af våben, står følgende om peberspray:

»3.2.1: Gassvåpen; CS-gas og OC-spray, må bare benyttes i særlige faresituasjoner eller når tjenestehandlingen ikke kan gjennomføres uten at politiperson utsettes for skade, jf våpeninstruksen $\S 17$ og når bruken fremstår som nødvendig, forsvarlig og forholdsmessig, jf politiloven $\S 6$, 4. ledd «.

Der stilles således de samme krav til brug af peberspray som til brug af politistav. Det fremgår endvidere, at det i den konkrete situation må vurderes, om peberspray skal anses som et mildere magtmiddel end fysisk magt. De norske regler ligner hermed de seneste svenske (se nedenfor), og synes generelt at udelukke brugen af spray i tilfælde, hvor politiet alene møder passiv modstand.

Som ovenfor nævnt, fører Politidirektoratet ikke nogen samlet statistik over indberetninger om brug af sprayen. Det er derfor ikke muligt at skabe noget mere præcist overblik over, hvor ofte den bruges i Norge. Jeg har dog modtaget tal for Oslo politidistrikt; disse vil blive nærmere beskrevet nedenfor i en sammenligning mellem København og Oslo.

\subsection{Peberspray i Sverige}

Sverige indførte OC-spray i 2004, efter at der var gennemført et forsøg med den i en række politidistrikter. Resultaterne var positive: OC-spray blev benyttet 242 gange i det år, forsøget løb (omkring 675 betjente deltog), og »enligt polismännens bedömning innebar OC-spray i 81 procent av fallen att ingripandet kunde genomföras med mindre våldsanvändning än vad som anners hade behövt vare fallet« (Rikspolisen 2007: 16). Ifølge evalueringen undgik politiet at benytte skydevåben i 17 tilfælde, og "tryggheten för alla inblandade parter har ökat" (Rikspolisstyrelsen 2004: 11).

I 2006-07 gennemførte Rikspolisstyrelsen en undersøgelse af brugen af OCspray. Det fremgår af evalueringen, at svensk politi i 2006 anvendte peberspray 1179 gange, men tilsyneladende var ikke alle svenske politifolk autoriseret til at bruge sprayen på dette tidspunkt, så tallet er ikke pålideligt som sammenligningsgrundlag med andre lande. Rapporten konkluderer, at »trösklen för när OC-spray 
skal användas er låg« (Rikspolisstyrelsen 2007: 4), og at der ofte sprayes på meget kort afstand, hvilket synes i modstrid med hensigten med indførelsen af sprayen. Samlet set herskede der ifølge undersøgelsen nogen forvirring om, hvornår sprayen måtte anvendes, og rapporten anbefalede at udarbejde et nyt regelsæt.

I 2009 udgav Justitieombudsmannen (JO) en kritisk rapport om brugen af peberspray. JO havde på eget initiativ gennemgået en lang række indberetninger om brug af peberspray (betjente, som anvender sprayen, skal i hvert enkelt tilfælde udfærdige en blanket om omstændighederne ved brugen) og havde her fundet 67 tilfælde, som umiddelbart forekom kritisable. ${ }^{11}$ Der var eksempler på, at OC var anvendt mod personer iført håndjern; mod personer som sad i politiets biler; mod anholdte, som allerede var indbragt til politistationen eller anbragt i venterum her; mod personer, som ikke fulgte politiets ordrer; mod personer, der var del af større forsamlinger, samt i situationer, hvor de ramte personer var i klart undertal i forhold til politiet. JO mente endvidere, at politiet $\mathrm{i}$ visse situationer brugte sprayen $\mathrm{i}$ rent præventiv hensigt, altså over for personer, som ikke i udgangspunktet udgjorde nogen trussel for politiet (Justitieombudsmannen 2009).

Ud over indberetningerne gennemgik JO også 10 retssager, som drejede sig om brugen af peberspray. Én var endnu ikke afgjort, syv endte i frifindelse, mens de anklagede betjente i to sager blev dømt for tjenestefejl. I den ene sag havde betjenten truet en mand med at sprøjte vedkommende $\mathrm{i}$ ansigtet, hvis denne ikke fortalte, hvor han havde gemt en kniv. I den anden sag dømtes en betjent for at have brugt sprayen på en person, der forsøgte at slide sig løs fra betjentens greb. Da der faktisk var to betjente til stede, mente retten, at personen kunne være tilbageholdt på anden vis.

Som led i sin undersøgelse bad JO såvel de lokale politimyndigheder, hvorfra de enkelte sager stammede, som Rikspolisstyrelsen (RPS) om at kommentere brugen af peberspray i de 67 sager. I tre sager mente myndighederne, at peberspray ikke burde have været anvendt, i tre andre sager kunne det ikke bedømmes grundet manglende oplysninger. I de resterende sager bakkede politimyndighederne op om brugen af spray. RPS meddelte mere generelt, at der efter styrelsens mening ikke var eksempler på, at peberspray blev brugt rent præventivt, samt at alt for mange sager måtte siges at være dårligt oplyst. Man ville derfor revidere indberetningsblanketten.

JO mente, at det hidtidige regelsæt, som tillod brug af spray, også selv om politiet ikke blev mødt med vold eller trussel om vold, var for lempeligt, og at regelsættet udvidede politiets magtbeføjelser ud over, hvad Polislagen tillod. JO lagde også vægt på, at brug af peberspray ikke burde opfattes som et »milt« men derimod som et »betydande mått av våldsanvändning« og konkluderede, at 
»[m]in uppfattning är att pepparsprayen vid en rangordning kan inordnas i just det tomrum som den ursprungligen var tänkt att fylla, nämligen som mera ingripande än närkampstekniker, som grepp och användande av batong, men självklart som betydligt mindre ingripande än användning av skjutvapen [...] Slutsatsen av min granskning är alltså att det är hög tid för RPS och de lokala polisledningarna att dra i handbromsen och motverka att det bland dess anställda sprids en uppfattning om att pepparspray medför ett våld av ganska milt slag och se till att den glidande utveckling som pågår stoppas upp« (JO 2009: afsnit 6.1.4 samt afsnit 7).

Efter JOs redegørelse reviderede RPS retningslinjerne for brug af spray, som nu lyder således:

》11 § OC-spray får användas bara om den polisiära uppgiften inte kan lösas på något annat, mindre ingripande, sätt och, bortsett från nöd- och nödvärnssituationer, aldrig utöver vad som stadgas om Polisens rätt att använda våld i $10 \S$ polislagen (1984:387). Användandet ska ske med hänsyn tagen till den smärta och det obehag som åtgärden innebär för den som utsätts för sprayen.

Endast om synnerliga skäl föreligger får OC-spray användas mot frihetsberövad vid transport i fordon under färd.

OC-spray får inte användas mot en person som endast gör passivt motstånd utan att använda egen kroppskraft.

Användning av OC-spray mot personer som utövar motstånd enbart genom att hålla sig fast i annan person eller föremål eller spjärna emot med ben eller armar, ska ske med stor restriktivitet.

OC-spray får inte användas generellt mot en folksamling. Innan OC-spray används mot en person som ingår $i$ en folksamling måste särskilda överväganden göras beträffande konsekvenserna av ett sådant användande« (RPS 2011:3)

Der er udfærdiget en ny indberetningsblanket, men der findes endnu ikke nogen national opgørelse af, hvor ofte sprayen anvendes.

\subsection{Peberspray i Danmark}

I Danmark gennemførtes i andet halvår af 2006 et forsøg med peberspray i tre politikredse i Østjylland. Kredsene havde i forsøgsperioden et indbyggertal svarende til otte procent af den danske befolkning, og kredsene var bemandet af otte procent af dansk politis operative personel (Politiets Årsberetning 2006). Af evalueringsrapporten (Rigspolitiet 2007) fremgår det, at erfaringerne er positive: Sprayen virker præventivt, mindsker risikoen for voldelige konfrontationer, mindsker behovet for brug af stav, og begrænser muligvis antallet af klager over politifolkenes adfærd.

Jeg har fået adgang til de rådata (statistisk opgørelse af de indberetninger om brug af spray, som findes fra forsøgsperioden), der ligger til grund for evaluerin- 
gen. I alt findes 87 indberetninger om brug af sprayen i andet halvår af 2006. I over halvdelen af indberetningerne ( $52 \mathrm{i}$ alt), angiver betjentene, at sprayen blev brugt i stedet for andre magtmidler (typisk politistav). Som det anføres i rapporten, er dette tal urealistisk højt: ${ }^{12}$

»Der er dog en tendens i indberetningsskemaerne til, at politifolkene mener, at de ville have anvendt staven i en række tilfælde, hvor de anvendte pebersprayen, men det underbygges altså ikke af de seneste års magtanvendelse, der, hvis det skulle påvirke virkeligheden, ville have været meget højere i forsøgskredsene i forsøgsperioden« (Rigspolitiet 2007: 7).

I 61 tilfælde var sprayen fuldt effektiv, dvs. den gjorde den ramte person ukampdygtig. I 16 tilfælde var der nogen, men ikke fuld effekt, mens de sidste 10 ramte personer ikke reagerede på sprayen overhovedet. Kun i fem tilfælde var brug af andre magtmidler nødvendig. 34 af de ramte var angiveligt berusede, 2 påvirkede af narkotika, og 4 påvirkede af begge dele. Ingen krævede lægehjælp grundet sprayen. Der foreligger ingen data om øvrige skader på hverken de ramte eller på politiet.

På baggrund af afprøvningen vurderedes sprayen at være et velegnet middel til at begrænse voldsomme episoder, og i løbet af 2008 fik alle landets politikredse peberspray. Ifølge politiets magtbekendtgørelse må peberspray kun anvendes

»med henblik på

1) at afværge et påbegyndt eller overhængende angreb på person,

2) at afværge overhængende fare i øvrigt for personers liv eller helbred,

3) at afværge et påbegyndt eller overhængende angreb på samfundsvigtige institutioner, virksomheder eller anlæg,

4) at afværge et påbegyndt eller overhængende angreb på ejendom,

5) at sikre gennemførelse af tjenestehandlinger, mod hvilke der gøres aktiv modstand, eller

6) at sikre gennemførelse af tjenestehandlinger, mod hvilke der gøres passiv modstand, såfremt tjenestehandlingens gennemførelse skønnes uopsættelig, og anden og mindre indgribende magtanvendelse skønnes åbenbart uegnet« (Bekendtgørelse 1430, § 25 a)

Som det fremgår, ligner reglerne generelt de nye svenske, og der er da også de samme krav om, at politiet så vidt muligt skal advare personen forinden brug af sprayen, samt at politiet efterfølgende skal hjælpe personen med at rense sprayen af. De danske regler afviger fra de svenske på ét punkt: Det er tilladt at bruge sprayen mod personer, der gør passiv modstand.

Der er indberetningspligt ved brug af peberspray i Danmark, og Rigspolitiet fører statistik over omfanget af brugen, se tabel 1. 
Tabel 1: Indberetninger om brug af peberspray, årsag til brugen og karakteristika ved de ramte personer, Danmark 2008-2011, eksklusiv Grønland og Fcerøerne. Procentdel af det samlede antal indberetninger i parentes.

\begin{tabular}{lrrrrrr}
\hline & $2008^{*}$ & 2009 & 2010 & 2011 & $\begin{array}{c}\text { Total } \\
\text { (pct. af total) }\end{array}$ \\
\hline Antal indberetninger & 1457 & 1427 & 1290 & 1654 & 5833 \\
Antal anholdte personer & 1072 & 1059 & 978 & 1334 & 4443 (76 pct.) \\
Grund til brug: Afværgelse af angreb mod person & 628 & 596 & 515 & 618 & 2357 (40 pct.) \\
Grund til brug: Afværgelse af andet angreb & 119 & 119 & 87 & 129 & 454 (8 pct.) \\
Grund til brug: Overvinde aktiv modstand & 852 & 869 & 835 & 966 & 3522 (60 pct.) \\
Grund til brug: Overvinde passiv modstand & 154 & 113 & 112 & 125 & 504 (9 pct.) \\
Ramt person: Beruset & 854 & 821 & 768 & 967 & 3410 (58 pct.) \\
Ramt person: Narkotikapåvirket & 236 & 272 & 269 & 354 & 1131 (19 pct.) \\
Ramt person: Psykisk syg & 187 & 210 & 167 & 190 & 754 (13 pct.) \\
\hline
\end{tabular}

*Note: I nogle politidistrikter blev peberspray først indført i de første måneder af 2008, og de samlede tal er derfor formentlig kunstigt lave. Grunde til brug af peberspray er ikke gensidigt udelukkende. Kilde: Rigspolitiet.

Som det ses i tabel 1, er der i en række tilfælde angivet mere end én grund til anvendelsen af peberspray. Desværre foreligger data ikke i en form, som gør mere dybtgående analyse mulig, og der foreligger ikke data om sprayens effektivitet. I øvrigt er det bemærkelsesværdigt, at der i lidt over halvdelen af indberetningerne ikke har været tale om angreb mod politiet (eller andre). Den hyppigste årsag til brug af peberspray er, at politiet møder aktiv modstand, og beruselse hos de ramte personer synes at være en væsentlig indikator for brugen: Næsten tre ud af fem ramte (58 pct.) bedømtes at være berusede. Under prøveperioden var andelen af berusede blandt de ramte mindre -44 pct. - men antallet af indberetninger fra $\mathrm{i}$ denne periode er så lille, at man næppe skal lægge for meget i det. Hver fjerde af de personer, som blev udsat for spray siden 2008, blev ikke anholdt. Det er ikke muligt ud fra de tilgængelige data at vurdere, om der er sammenhæng mellem beruselse og odds for anholdelse. Det står dog klart, at ikke alle berusede blev anholdt, da antallet af anholdte i nogle politikredse i nogle måneder er mindre end antallet af ramte berusede personer. I 87 pct. af indberetningerne blev der efterfølgende journaliseret en sag vedr. den person, der blev ramt af peberspray.

Et væsentligt spørgsmål er, om peberspray er anvendt $\mathrm{i}$ stedet for andre magtmidler. Dette findes der imidlertid ikke data, der kan belyse. ${ }^{13}$ Der er derfor 
kun den mulighed at sammenligne tal for brug af stav og pistol før og efter indførelsen af peberspray, se figur 1 .

Figur 1. Politiets brug af stav, skydevåben og peberspray i Danmark 2000-2011

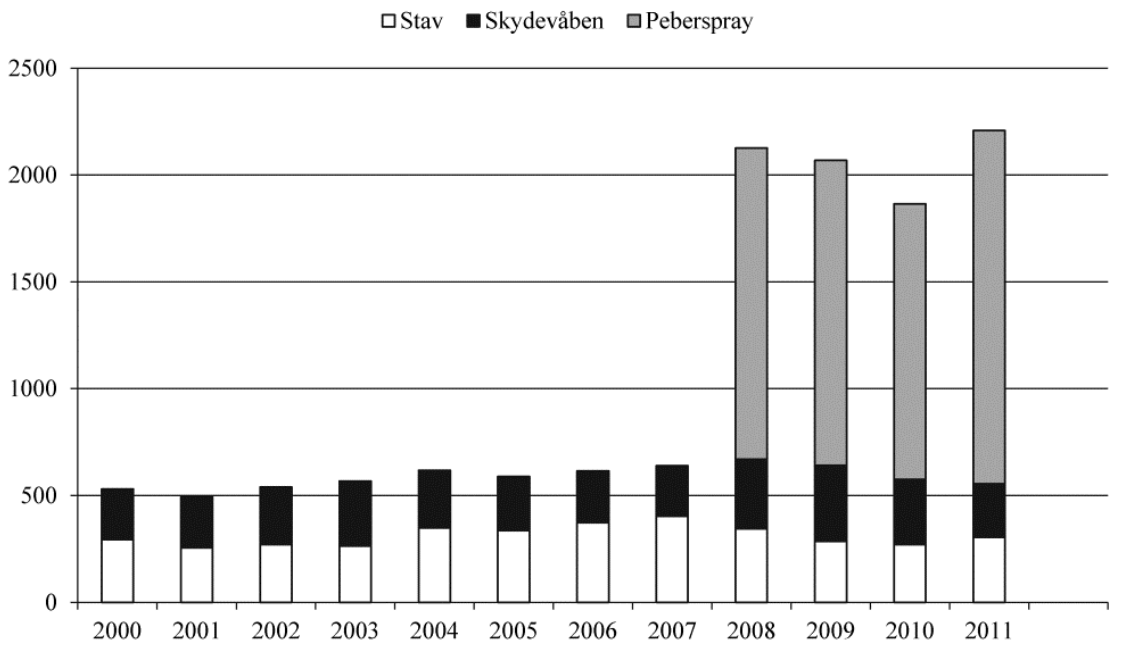

Som det ses i figur 1, steg politiets brug af stav fra 2001 til 2008, samtidig med at brug af skydevåben (inklusive trussel om brug) var nogenlunde konstant. Fra 2008-2011 faldt brugen af andre magtmidler med 17 pct., og er i 2011 på niveau med år 2003. Samtidig er det dog klart, at indførelsen af peberspray har betydet, at det samlede antal indberetninger om brug af magtmidler er blevet mere end tredoblet. Reduktionen i brug af staven fra 2007-2010 kunne indikere, at pebersprayen har haft en betydning, men det ses umiddelbart, at denne i bedste fald er meget begrænset, og at antallet af indberetninger i øvrigt svinger en del fra år til år. Reduktionen i brug af stav kan derfor tænkes at være påvirket af andre faktorer, og faldet er i øvrigt ikke fortsat i 2011, selv om pebersprayen her blev brugt endnu hyppigere end i de forrige år. På denne baggrund kan der ikke siges noget sikkert om pebersprayens betydning for brug af staven - ud over at det er højst usandsynligt, at pebersprayen har afløst brug af stav i den grad, som det angiveligt var tilfældet i prøveperioden. Da kun en mindre del af indberetningerne (9 pct.) omhandler passiv modstand, er det nærliggende at tro, at pebersprayen i en 
række tilfælde har afløst brug af fysisk magt (som ikke indberettes) på samme måde, som det skete i Holland (Kaminski og Adang 2010).

\section{Peberspray i Danmark og Norge - en sammenligning}

De tilgængelige data giver kun begrænsede muligheder for at sammenligne brugen af peberspray i Danmark med de andre skandinaviske lande. Hverken i Sverige eller i Norge findes der nationale tal for brug af peberspray (eller national statistik for brug af stav).

Det er muligt at sammenligne brugen af sprayen i Danmark og Sverige i forsøgsperioderne, og en sådan sammenligning tyder på, at der ikke var den store forskel mellem de to lande. ${ }^{14}$ En sammenligning mellem brugen i Sverige i 2006 og i Danmark i årene efter vanskeliggøres som tidligere nævnt af, at det er usikkert, om alle svenske politifolk havde adgang til sprayen i 2006. Hvis dette (tilnærmelsesvis) var tilfældet, synes den svenske brug af sprayen at ligge noget under den danske.

En sammenligning mellem den norske og den danske afprøvning af sprayen vanskeliggøres af, at det er uklart, hvornår hele det norske politi var udstyret med spray. Hertil kommer, at den danske afprøvning fandt sted to år senere, hovedsagelig i storbyen Århus, hvor politiet kunne formodes at komme i konfrontationer med borgerne noget hyppigere, end det sker på landsplan. Selv med disse forbehold synes det dog sikkert, at dansk politi brugte peberspray langt hyppigere end det norske: I Norge var det samlede antal indberetninger for stort set hele landet $i$ prøveperioden på to år 247. I Danmark blev pebersprayen anvendt 87 gange på et halvt år i et område, der omfattede otte pct. af landets befolkning og politistyrke. Omregnet til landsplan ville dette svare til over 2.000 anvendelser pr. år i Danmark, altså som forventet lidt over det faktiske gennemsnit - 1458 - $\mathrm{i}$ årene efter.

Der findes dog én mulighed for en mere direkte sammenligning mellem de to lande: Der findes tal for brugen af peberspray i de to landes hovedstæder, som er tilnærmelsesvis ens, hvad indbyggertal og politidækning angår. ${ }^{15}$ Antallet af indberetninger vedr. brug af peberspray fremgår af tabel 2 .

Tabel 2: Antal indberetninger vedr. politiets brug af peberspray i Oslo politidistrikt 2005-2011 og Københavns politikreds 2008-2011

\begin{tabular}{lrrrrrrr}
\hline & 2005 & 2006 & 2007 & 2008 & 2009 & 2010 & 2011 \\
\hline Antal indberetninger, Oslo & 49 & 36 & 22 & 21 & 9 & 23 & 31 \\
Antal indberetninger, København & - & - & - & 359 & 382 & 303 & 375 \\
\hline
\end{tabular}

Note: Data oplyst af Oslo politidistrikt og Rigspolitiet 
Det fremgår umiddelbart, at brugen af peberspray stort set ophørte i Oslo i 2009, hvilket muligvis kan tilskrives problemerne med uddannelse af personalet, som blev beskrevet ovenfor. Det fremgår også, at Københavns politi også i de seneste år brugte peberspray mere end 10 gange så hyppigt som Oslos politi. Det er dog muligt, at det i 2011 fortsat ikke er hele Oslos politistyrke, som er godkendt til at bruge sprayen, og at sammenligningen derfor bliver skæv. Hvis vi i stedet tager udgangspunkt i 2005, hvor brugen af peberspray i Oslo toppede, er den gennemsnitlige brug i København (355 årlige indberetninger i hele perioden) omkring syv gange så høj som i Oslo.

At der er væsentlig forskel mellem omfanget af OC-brug i Norge og Danmark bekræftes af de oplysninger, jeg har fået fra tre øvrige norske politidistrikter. Således angiver Søndre Buskerud politidistrikt, at OC-spray anvendes 10-12 gange årligt, mens Vestfold politidistrikt i perioden 2008-11 anvendte spray mellem 6 og 17 gange årligt, svarende til et gennemsnit på 12. Endelig angav Vestoppland politidistrikt, at sprayen blev anvendt 3 gange i 2011.

Samlet set er der på denne baggrund næppe tvivl om, at dansk politi bruger peberspray langt oftere end norsk politi. Den præcise faktor kan ikke beregnes, men et rimeligt gæt vil være fem til syv gange så ofte.

\subsection{Kan forskellen forklares?}

En umiddelbar forklaring kan naturligvis være, at rapporteringen er langt mere nøjagtig i Danmark. Dette burde dog ikke være noget stort problem, hvad angår de to forsøgsperioder, hvor man må antage, at der er gjort mest muligt for at sikre, at de indkomne data er korrekte. Selv om der er visse usikkerheder forbundet med det norske forsøg, fordi ikke alle politifolk var autoriserede til at bruge sprayen fra starten, kan dette dog næppe forklare, at dansk politi brugte sprayen mere end 10 gange så ofte som norsk politi i forsøgsperioden. Hvad angår sammenligningen mellem Oslo og København, er der ikke noget, som indikerer, at manglende indberetninger skulle være et særligt problem i Oslo politidistrikt, så unøjagtighed i rapportering må antages højst at kunne forklare en del af forskellen i forhold til Danmark.

Det er også muligt, at politifolk i Danmark oftere udsættes for angreb end deres kolleger i Norge. Denne forklaring finder en vis støtte i de respektive landes kriminalstatistik. Således var der i 201027 anmeldelser pr. 100.000 indbyggere om vold mod personer i offentlig tjeneste i Norge, mens tallet i Danmark var 49. Der skal dog her tages forbehold for mulige forskelle i, hvilke delikter, der er omfattet af de respektive paragraffer, forskelle mht. hvilke faggrupper ud over politiet, der er omfattet, samt for mulige forskelle i anmeldelsestilbøjelighed. Det hører 
også med til billedet, at sigtelser vedr. vold mod politiet blandt andet opstår i forbindelse med, at personer forsøger at modsætte sig anholdelse. Politiets håndtering af modvillige anholdte kan derfor have indflydelse på antallet af sager. Selv hvis danske politifolks risiko for at blive angrebet er næsten dobbelt så stor som deres norske kollegers, forklarer dette ikke i sig selv, at de bruger peberspray fem-syv gange så ofte. Det fremgår i øvrigt af tabel 1 ovenfor, at det danske politi »kun« brugte peberspray til at afværge et overhængende eller påbegyndt angreb i 48 procent af tilfældene.

Selv hvis det antages, at der er forskelle mellem Danmark og Norge, både hvad angår rapporteringspraksis og politifolkenes udsathed for angreb, synes det usandsynligt, at disse forhold kan forklare hele forskellen i brugen af peberspray. Man må derfor se på, om andre forhold kan spille en rolle, og her er det nærliggende at se på reglerne om brug af spray. Danmark adskiller sig fra både Norge og Sverige ved at tillade brug af peberspray mod personer, som alene yder passiv modstand. Hvor brug i Norge kræver særlige faresituationer eller risiko for skade på politiet (eller andre), er den nedre grænse i Danmark, og at anden form for indgriben over for en person, som yder passiv modstand, er »åbenbart uegnet«, samt at »tjenestehandlingen er uopsættelig«. Der er altså ikke krav om, at betjentene skal føle, at der er fare for dem selv eller andre. Denne form for brug udgør ganske vist kun 9 pct. af de danske indberetninger ${ }^{16}$ men det, at den overhovedet er tilladt, kan tænkes at have afsmittende virkninger. Når sprayen må bruges i situationer, hvor politiet ikke umiddelbart er truet, kan det bidrage til opfattelsen af, at peberspray udgør en meget mild form for magtanvendelse, hvilket igen kan føre til hyppigere brug. Denne argumentation finder støtte i tidligere forskning fra Holland (Adang og Mensink 2007), samt indirekte fra en nordisk undersøgelse vedr. politiets brug af skydevåben, hvori det konkluderes, at politiets »vapenpolicy« har stor betydning for, hvor ofte og hvordan skydevåben benyttes (Knutsson og Norée 2005).

\section{Peberspray i Danmark: et udvidet anvendelsesområde?}

Afslutningsvis er der grund til at se nærmere på den danske udvikling i brugen af magtmidler før og efter pebersprayens indførelse. Sprayen er blevet anvendt mere end 1450 gange om året i perioden 2008-2011, uden at dette umiddelbart ser ud til at have påvirket brugen af andre magtmidler (stav og skydevåben) væsentligt. Vurderingen heraf vanskeliggøres dog af, at de danske data kun giver mulighed for en begrænset (og videnskabeligt set ikke ganske tilfredsstillende) analyse. Der er alene tale om en sammenligning af den indberettede magtanvendelse før og efter indførelsen af sprayen, og den samlede udvikling i politiets brug af magtmid- 
ler kan være påvirket af omstændigheder, som ikke er direkte relateret til tilgængeligheden af sprayen.

For det første kan det tænkes, at antallet af borgere, som gør modstand over for politiet er steget i de senere år, hvilket kunne forklare, at antallet af episoder, hvor politiet har måttet bruge magtmidler, er steget. ${ }^{17}$ Selv om det er teoretisk muligt, er det dog højst usandsynligt, at der skulle være sket en så markant - og pludselig - stigning i den faktiske vold mod politiet, at det i sig selv kunne forklare, at den samlede brug af magtmidler fra det ene år til det andet er mere end tredoblet.

En anden mulighed er, at peberspray udbedrer en væsentlig, men hidtil upåagtet, mangel i politiets mulighed for at beskytte sig selv. Dette er dog næppe sandsynligt, dels fordi et problem af et sådant omfang ville være blevet bemærket, dels fordi det fremgår af rapporten om det danske forsøg, at det er Rigspolitiet, der med inspiration fra særlig Sverige har besluttet at afprøve sprayen (Rigspolitiet 2007).

Mere sandsynligt er det, at pebersprayen i en række situationer har afløst brugen af fysisk magt (i form af håndkraft, greb m.v., som ikke indberettes), sådan som det også er foreslået for Hollands vedkommende (Kaminski og Adang 2010). Det fremgår dog af indberetningerne, at pebersprayen også er anvendt i en række situationer, hvor politiet ikke var udsat for fysisk modstand.

Dette tyder på, at de danske politifolk, i lighed med deres kolleger i Holland, i en række situationer bruger sprayen, også selv om der ikke umiddelbart er fare for, at de selv eller andre bliver angrebet - at sprayen altså bliver brugt $i$ en form for præventiv hensigt. Det faktum, at sprayen i udstrakt grad bruges mod »spirituspåvirkede personer, som laver uro på gaden i nattetimerne«, som Rigspolitiet har formuleret det, ${ }^{18}$ kunne indikere, at sprayen i visse tilfælde bruges som en hurtig løsning i forhold til ordensproblemer, som ellers kan være tidskrævende at håndtere. Den måde, pebersprayens virkning beskrives på - et forbigående, om end kraftigt ubehag, uden risiko for varige skader - kan være medvirkende til, at politifolkene oplever brugen af spray som uproblematisk, også selv om der ikke umiddelbart er fare for fysisk konfrontation.

Selv om en sådan anvendelse ligger inden for reglerne for brug af sprayen, var det ikke med det formål, den blev indført; målet var først og fremmest, at sprayen »kan medvirke til, at der sker færre skader på både borgere og politifolk under anholdelser, idet voldsomme anholdelser med for eksempel anvendelse af staven, i større omfang kan undgås « (Rigspolitiet 2007: 12). Som beskrevet ovenfor, har pebersprayen næppe haft nogen væsentlig indflydelse på brug af stav (og pistol). Brugen af peberspray i Danmark kunne således være et eksempel på, hvad der på 
engelsk kaldes »function creep« (Fox 2001) og i Norge kaldes »formålsutglidning« (NOU 2009) - altså at anvendelsesområdet udvides ud over, hvad der oprindelig var tænkt. Udviklingen ligner dermed, hvad der er set i Holland (Adang og Mensink 2007) og i Sverige, hvor det netop var benyttelsen af peberspray i situationer, hvor politiet slet ikke var udsat for trusler/angreb, som Justitieombudsmannen (2009) fandt behov for at gribe ind over for.

De danske data giver som nævnt ikke mulighed for nærmere analyse, og de forslag til forklaring på den hyppige danske brug af peberspray, der er fremlagt her, må i sagens natur være spekulative. En mere dybtgående undersøgelse ville med fordel kunne tage udgangspunkt $i$ de enkelte indberetninger og dermed give et mere fyldestgørende svar på, i hvilke situationer pebersprayen anvendes. Det ville også være værd at undersøge, hvilken betydning indførelsen af sprayen har haft for politiets og borgernes risiko for at komme til skade under anholdelser m.v. Den danske evalueringsrapport konkluderer forsigtigt, at »der kan være tale om en tendens i retning af, at voldsomme anholdelser forekommer sjældnere, og at der derved sker færre skader « (Rigspolitiet 2007: 8) men gør samtidig opmærksom på, at denne konklusion er usikker, da den bygger på et meget lille talmateriale. Set i lyset af, at en langt mere omfattende undersøgelse fra USA (Smith et al 2010) viser, at anvendelse af peberspray er forbundet med en foroget risiko for, at politifolk kommer til skade, synes der at være god grund til at undersøge spørgsmålet nærmere. ${ }^{19}$ Endelig ville det være nærliggende at undersøge, hvordan danske politifolk opfatter peberspray, og hvor på det såkaldte magtbarometer, de mener, den hører til.

\section{Konklusion}

Peberspray blev indført i Danmark i forventning om, at den kunne begrænse behovet for at bruge andre, farligere magtmidler (først og fremmest staven), og at den ville beskytte politifolk og borgere mod overlast. Hvad det sidste angår, findes der, så vidt vides, ikke nogen nærmere undersøgelse heraf. Hvad det første angår, er virkningen i bedste fald stærkt begrænset: Efter den landsdækkende indførelse bruges sprayen 1200-1600 gange hvert år, mens antallet af indberetninger om brug af stav og skydevåben er reduceret med lidt over 100 indberetninger i forhold til højdepunktet i 2008.

En sammenligning af de danske, svenske og norske regler viser, at danske politifolk må bruge sprayen i situationer, hvor deres norske og svenske kolleger ikke må. Hvad den faktiske anvendelse angår, er det grundet manglende data ikke muligt at sammenligne med Sverige, mens der for Norges vedkommende findes begrænsede muligheder for sammenligning. På det foreliggende grundlag er det 
dog rimeligt at konkludere, at brugen af peberspray i Danmark i omfang ligger langt over niveauet i Norge, og at det er sandsynligt, at de mere lempelige danske regler vedr. brugen er en medvirkende årsag.

I Rigspolitiets evalueringsrapport, som anbefaler indførelsen af peberspray, står følgende: »Når dansk politi indfører supplerende tekniske magtmidler, vil de blive anvendt overfor borgerne. Samtidig har politifolkene et nyt magtmiddel at tage stilling til og tage ansvaret for. Det er også en kendt mekanisme, at indførte magtmidler forbliver, idet en eventuel debat om afskaffelse af dem, kan blive en debat om sikkerhed « (2007: 12). Erfaringerne fra årene efter viser, at peberspray ikke bare er blevet anvendt, men også anvendt i et ganske stort omfang - indberetninger om politiets brug af magtmidler er mere end tredoblet efter indførelsen af sprayen.

I denne sammenhæng er det værd at påpege, at der i Danmark, lige som i en række andre lande, lægges meget lidt vægt på, at brug af peberspray udgør, hvad det svenske politi kalder »et betydande mått av voldsanvändning« (RPS 2011:3); det er yderst smertefuldt at blive ramt af sprayen, og hos nogle giver det anledning til panik. Det faktum, at der stort set aldrig ses varige, fysiske skader ved brug af sprayen, kan på den baggrund kun være et argument for at bruge den $i$ stedet for andre former for fysisk magt - ikke for at bruge den i situationer, som kunne være løst på anden vis. I hvilket omfang, dette sker i Danmark, eller, mere overordnet, hvorvidt det danske politi bruger sprayen for ofte, kan ikke afgøres på det foreliggende grundlag. Den påviste forskel mellem Norge og Danmark, samt den nylige stramning af de svenske regler, kunne være en anledning til en mere dybtgående undersøgelse af dansk politis anvendelse af dets nyeste magtmiddel.

\section{Noter}

1. Lars Holmberg, ph.d., er lektor i kriminologi ved Det Juridiske Fakultet, Københavns Universitet.

2. I Norge har der ganske vist også været en del diskussion, men det har alene været spørgsmålet om, hvorvidt politifolk måtte udsættes for sprayen i forbindelse med deres uddannelse. Nærmere herom i afsnittet om Norge.

3. Der findes også en variant, PAVA, som kan fremstilles syntetisk, men virkningen er stort set den samme.

4. Peberspray bruges også i en række lande i fængsler og arresthuse, men dette vil ikke blive berørt her.

5. Procentsatsen varierer alt efter, hvor mange forskellige variable, der er medtaget $i$ de anvendte regressionsanalyser. I undersøgelsen indgår et meget stort antal, 24.000, rapporter om brug af magtmidler, herunder stav, OC, Taser og skydevåben. 
6. Da det samlede antal sager, som indgår i denne undersøgelse er ganske lille (i alt 61 rapporter om brug af magt fordelt på før, under og efter at sprayen var tilladt), må resultaterne vurderes med nogen skepsis.

7. Hentet $04.01,2013$ på http://www.youtube.com/watch?v=FBk $\operatorname{logP} 18 \mathrm{~K} 0$. Den pågældende betjent blev efterfølgende suspenderet, men det faktum, at han brugte sprayen foran et større presseopbud tyder på, at han mente at have reglementet på sin side.

8. Det vides ikke, om der er gennemført en afprøvning i Island.

9. Jeg vil gerne i denne forbindelse takke en lang række personer og organisationer, som har hjulpet mig med at fremskaffe oplysninger: Rigspolitiet i Danmark, Politidirektoratet i Norge samt en række norske politidistrikter, Jo Hvile, Johannes Knutsson, Anders Lohne Lie, Jon Strype, and Per Olav Torkildsen fra Politihøgskolen i Oslo; Stefan Holgersson, Linköping Universitet; Bengt Bergman, Polishögskolan i Solna; Vesa Huotari and Tomi Kataja, Polisyrkeshögskolan i Tampere; Ragnheidur Bragadottir, Islands Universitet.

10. Denne sag er grundigt dækket i magasinet Politiforum (januar 2007, februar 2007, april 2007, august 2008)

11. Et referat af disse sager findes på Justitieombudsmannens hjemmeside: http://www.jo.se/ Page. aspx?MenuId=106\&MainMenuId $=106 \&$ Language $=$ sv\&ObjectClass $=$ DynamX SFS Decision\&Id=4333 (Hentet 04.012013 )

12. Dansk politi anvendte stav 372 gange i 2006, og skulle det passe, at peberspray havde afløst staven 52 gange på et halvt år i forsøgskredsene, ville de tre politikredse altså samlet set stå for mere end en fjerdedel af al brug af stav i Danmark.

13. Som tidligere nævnt, ville sådanne data sandsynligvis give et fortegnet billede af, hvor ofte sprayen erstattede andre magtmidler, fordi vurderingen ville bero på de enkelte betjentes indberetning.

14. Omfanget af spraybrugen i forsøgsperioderne i Danmark og Sverige er tilnærmelsesvis ens: I Danmark benyttede hver af de deltagende betjente i gennemsnit peberspray 0,30 gange, mens de svenske benyttede sprayen 0,36 gange. Forsøgsområderne er dog ikke umiddelbart sammenlignelige. Under alle omstændigheder er det klart, at sprayen blev benyttet langt oftere i Sverige end i Norge i forsøgsperioderne.

15. Oslo politidistrikt havde i 2009570.000 indbyggere og 2.600 ansatte i politiet (inklusiv civilt ansatte) mens Københavns politikreds i 2012 havde 630.000 indbyggere og 2.600 ansatte i politiet inklusiv civile.

16. Dette naturligvis under forudsætning af, at årsagen til brugen i Danmark er korrekt indberettet, hvilket det ikke har været muligt at undersøge ved hjælp af de foreliggende data.

17. Antallet af anmeldelser om vold mod offentlig myndighed steg fra 1880 i 2000 til 3071 i 2006, og faldt igen til 2840 i 2011. En del af stigningen kan muligvis tilskrives en øget anmeldelsestilbøjelighed blandt myndighedsudøverne. Der foreligger ikke systematiske undersøgelser heraf, men det er nærliggende at tro, at den generelt øgede anmeldelsestilbøjelighed vedr. vold i befolkningen som helhed (se f.eks. Balvig og Kyvsgaard 2010) kan genfindes hos politipersonalet.

18. Rigspolitiets pressemeddelelse af 16. marts 2009. Hentet 03.01, 2013, fra https://www.politi.dk/ da/aktuelt/nyheder/2009/peberspray08_16032009.htm.

19. Det er et åbent spørgsmål, om de amerikanske resultater kan overføres til Danmark, da politiets arbejdsbetingelser i de to lande er meget forskellige. 


\section{Referencer}

Adang, O.M.J. og Mensink, J. (2007): Pepper Spray: An Unreasonable Response to Subject Verbal Resistance, Policing: An International Journal of Police Strategy and Management, 27(2), 206-219.

Adang, O.M.J., Kaminski, R.J., Howell, M-Q. og Mensink, J. (2006): Assessing the Performance of Pepper Spray in Use-of-Force Encounters: the Dutch Experience, Policing: An International Journal of Police Strategy and Management, 29(2), 282-305.

Arbeidstilsynet (2007): Vedtak om pålegg - politiets opplaering i bruk av pepperspray. Arbeidstilsynet, Oslo.

Bowling, J.M. og Gaines, M. (2000): Evaluation of Oleoresin Capsicum (O.C.) Use by Law Enforcement Agencies: Impact on Injuries to Officers and Suspects, Final Activity Report, NCJRS, Hentet 04.01, 2013 på: https://www.ncjrs.gov/pdffiles1/nij/grants/184934.pdf

Busker, R.W. og van Helden, H.P.M. (1998): Toxicologic Evaluation of Pepper Spray as a Weapon for the Dutch Police Force: Risk Assessment and Efficacy« The American Journal of Forensic Medicine and Pathology, 19(4), 309-316.

Buttle, J.W. (2006): Unravelling the »Velcro Effect«: Is deterring assaults against the police indicative of a more aggressive style of policing? International Journal of Police Science and Management, 8(2), 133-142.

Edwards, S.M. Granfield, J. og Onnen, J. (1995): Pepper Spray Evaluation Project. Results of the Introduction of Oleoresin Capsicum (OC) into the Baltimore County, MD, Police Department. Washington, IACP.

Justitieombudsmannen (2009): Milt eller betydande våld? En granskning av polisens bruk af pepparspray, JO beslut 2009-12-01. Hentet 04.01, 2013 på http://www.jo.se/ Page.aspx?MenuId=106ogMainMenuId=106ogLanguage $=$ svogObjectClass $=$ DynamX_SFS DecisionogId=4329

Kaminski, R.J. og Adang, O. (2010): Pepper Spray: Practice, Policy, and Research in the Netherlands, i Kuhns og Knutsson (red.): Police Use of Force: a Global Perspective, Praeger, Santa Barbara, 167-176.

Kaminski, R.J., Edwards, S.M. og Johnson, J.W. (1999): Assessing the Incapacitative Effects of Pepper Spray During Resistive Encounters With the Police, Policing: An International Journal of Police Strategy and Management, 22(1), 7-29.

Kaminski, R.J., Edwards, S.M. og Johnson, J.W. (1998): The Deterrent Effects of Oleoresin Capsicum on Assaults against Police: Testing the Velcro-Effect Hypothesis, Police Quarterly, 1(2), 1-20.

Knutsson, J. og Norée, A. (2005): Polisers bruk av skjutvapen i Norden - en jämförelse, i Knutsson (red.): Politiets bruk av skytevåpen i Norden, Oslo, Politihøgskolen.

Lumb, R.C. og Friday. P.C. (1997): Impact of Pepper Spray Availability on Police Officer Useof-Force Decisions, Policing: An International Journal of Police Strategy and Management, 20(1), 136-148.

Morabito, E.V. og Doerner, W.G. (1997): Police Use of Less-than-Lethal Force: Oleoresin Capsicum (OC) Spray, Policing: An International Journal of Police Strategy and Management, 20(4), 680-697.

NIJ (2003): The Effectiveness and Safety of Pepper Spray. Research for Practice, April 03. National Institute of Justice. 
NOU (2009): Individ og integritet. Personvern i det digitale samfunnet. Norges Offentlige Utredninger 2009:1

Politiets data- og materielltjeneste og Politihøgskolen (2007), OC Pepparspray. Evaluering av 2-årig prøveprosjekt (2003-2004), Politihøgskolen, Oslo.

Rappert, B. (2007): Policing and the Use of Force: Less-lethal Weapons, Policing - A Journal of Policy and Practice, 1(4), 472-484.

Rappert, B. (2002): Assessing chemical Incapacitant Sprays, International Journal of Police Science og Management, 4(2), 115-126.

Rigspolitiet (2007): Evaluering af forsøg med peberspray, Rigspolitiet, København.

Rikspolisstyrelsen (2011): Rikspolisstyrelsens författningssamling: Rikspolisstyrelsens föreskrifter och allmänna råd om OC-spray (pepparspray). RPSSF 2011:17, FAP 104-4

Rikspolisstyrelsen (2007): Granskning av användningen av OC-spray - Polismyndighetarna $i$ Västmanlands län och Skåne. Enheten för inspektioner, Stockholm.

Rikspolisstyrelsen (2004): Fältförsök OC - Slutrapport. Rikspolisstyrelsen 2004-01-16.

Smith, C.G. og Stopford, W. (1999): Health Hazards of Pepper Spray, NCMJ, 60(5), 268-274.

Smith, M.R., Kaminski, R.J., Alpert, G.P., Fridell, L.A., MacDonald, J. og Kubu, B. (2010): A Multi-Method Evaluation of Police Use of Force Outcomes: Final Report to the National Institute of Justice. US Department of Justice, Document No. 231176.

Smith, J. og Greaves, I. (2002): The Use of Chemical Incapacitant Sprays: A Review. The Journal of TRAUMA Injury, Infection, and Critical Care, 52, 595-600.

Smith, M.R. og Alpert, G.P. (2000): Pepper Spray: A Safe and Reasonable Response to Subject Verbal Resistance. Policing: An International Journal of Police Strategy and Management, 30(3), 341-357.

Terrill, W., Paoline III, E.A., og Ingram, J. (2012): Final Technical Report Draft: Assessing Police Use of Force Policy and Outcomes. US Department of Justice, Document No.: 237794

Vesaluoma, M., Müller, L., Gallar, J., Lambiase, A., Moilainen, J., Hack, T., Belmonte, C. og Tervo, T. (2000): Effects of Oleoresin Capsicum Pepper Spray on Human Corneal Morphology and Sensitivity. Investigative Ophthalmology and Visual Science, 41(8), 2138-2147

Vilke, G.M. og Chan, T.C. (2007): Less lethal technology: medical issues. Policing: An International Journal of Police Strategy and Management, 23(2), 233-245.

Weaver, W. og Jett, M.B. (1989): Chemical agents research: Oleoresin Capsicum. FBI firearms training unit, Quantico VA. 